\title{
Coulisses
}

Revue de théâtre

\section{Les suites des premières rencontres}

\section{Claire Garbagnati}

\section{OpenEdition}

Journals

Édition électronique

URL : http://journals.openedition.org/coulisses/1654

DOI : 10.4000/coulisses. 1654

ISSN : 2546-9460

\section{Éditeur}

Presses universitaires de Franche-Comté

\section{Édition imprimée}

Date de publication : 1 février 1991

Pagination : 59

ISSN : 1150-594X

\section{Référence électronique}

Claire Garbagnati, «Les suites des premières rencontres », Coulisses [En ligne], 3 | Hiver 1991, mis en ligne le 04 juillet 2017, consulté le 23 octobre 2019. URL : http://journals.openedition.org/coulisses/ 1654 ; DOI : 10.4000/coulisses. 1654

Ce document a été généré automatiquement le 23 octobre 2019

Coulisses 


\section{Les suites des premières rencontres}

\section{Claire Garbagnati}

\section{NOTE DE L'AUTEUR}

Étant moi-même d'une grande école, je n'entends nullement afficher un racisme « antigrandes écoles, par jalousie envers les opportunités dont leurs étudiants jouissent ; je me permets seulement de constater la facilité parfois écœurante dont ils bénéficient pour trouver des fonds, alors même que leurs prestations ne sont pas toujours d'excellente qualité.

Pour que talent et moyens fassent enfin bon ménage, on peut toujours rêver! Pourquoi les troupes universitaires ne se feraient-elles pas sponsoriser par les grandes écoles? 


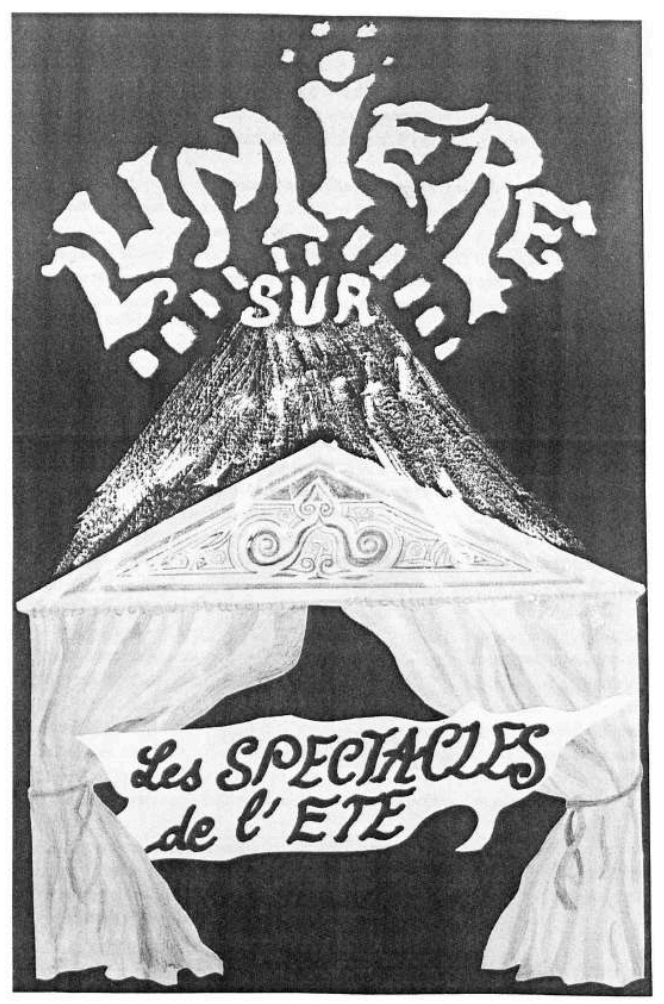

1 S'initier à la pratique des danses folkloriques russes d'après les recommandations, $\hat{o}$ combien didactiques, d'une austère revue musicale ou jouer de l'accordéon sur une caisse à outils dépliable ; se faire offrir un copieux sandwich en guise de lait-fraise, à la terrasse d'un café ou devenir fou en prenant son petit déjeuner ; mimer un article du Démocrate ou gagner du temps en apprenant à décoder et utiliser un langage composé de sigles et initiales; se faire passer, tout à tour, pour un ecclésiastique ou une petite dame promenant et dorlotant bébé, alors que, arborant barbe et moustache, on est taillé comme Tarzan...

2 Voilà, puisés au hasard, quelques extraits du Festival de Mime et Café-Théâtre Universitaires auquel était invité le TUFC.

3 Mes excuses à tous ceux que j'ai oubliés, et mes félicitations aux organisateurs, qui ont su faire se succéder comiques de situation, comédies de boulevard, matches de boxe, bulletins météo, conférences au ton grave et mîmes à vocation esthétique... Un programme on ne peut plus varié, d'une surprenante qualité... et des efforts couronnés de succès. Pour preuve : personne n'a quitté l'amphithéâtre bondé, en dépit des sièges particulièrement inconfortables et d'une chaleur insoutenable...

4 Douze spectacles par soir, trois heures durant... On peut cependant regretter qu'aucun entr'acte n'ait été prévu...

5 Une mention spéciale, cependant, aux troupes camerounaises et de Côte d'Ivoire, pour la bonne humeur et la gaîté qu'elles ont apportées, une vision africaine de l'immigration, qui change agréablement du trop ressassé humour «beur », et, pour une fois, interprétée par des Africains, et non des blancs, qui « jouent au négwe ».

6 Pas une seule représentation ne ressemblait à une autre: diversité, imagination et créativité... sans, pour autant, une once de prétention. 
7 Quand je pense, qu'au même moment, le Festival de théâtre des Grandes Écoles bénéficiait des somptueuses installations du Théâtre du Ranelagh, et exposait des têtes d'affiches telles qu'Alain Delon!

8 Ici, installations et décors pauvres. Remise des récompenses presque confidentielle. Ici, on est venu avec ce que l'on avait, et ce que l'on a, c'est, avant tout, du talent, et une grande passion : le Théâtre.

9 Encore bravo et Merci !!

10 Affaire à suivre...

11 N.B. : il ne s'agit pas d'une ruse destinée à inciter le lecteur à acheter le numéro suivant! 